\title{
\begin{tabular}{l|l|l} 
& Jurnal Kependidikan Dasar & $\begin{array}{l}\text { Volume : } 2 \\
\text { Nomor :2 } \\
\text { Tahun : } 2017\end{array}$ \\
\hline
\end{tabular}
}

\section{Pengaruh Kemampuan Membaca Pemahaman Terhadap Prestasi Belajar Matematika Pada Pokok Bahasan Soal Cerita Kelas IV}

\author{
Hendra Erik Rudyanto \\ Dosen Prodi PGSD Universitas PGRI Madiun \\ Surel : hendraerik081@gmail.com
}

\begin{abstract}
Reading, writing and arithmetic are the unity that becomes the habit of everyone. Especially for student, no day without these three activities. When the student face obstacles in understanding the content of the story, then the student will be difficult to solve of the problem well. Thus, the student's achievement will decrease due to repeatedly making mistakes in solving the problem. The purpose of this research is to proven is there any effect between reading comprehension ability and the achievement of learning mathematics on the subject matter of the story test student class IV 02 Kertosari Elementary School in the academic year 2016/2017. This research is quantitative research. The population of this research is the student's of 02 Kertosari Elementary School with total 28 student from two schools in Kertosari. The sampling technique used was saturated sampling technique, so that in the population used as a sample as a whole. Data collection method used was multiple choice tests on variable $X$ and tests essay on variable $Y$. The prerequisites test used was normality test, linearity test and homogenity test. The analysis of the data used simple linear regression with counted score a, score $b$, score $r$, score $t$, and also the coefficient determination to knew how much contribution between variables. Based on the result of the'research, coefficient determination were collected 0,5254 or $52,54 \%$ and the rest is affected by another variable. So, it can be concluded that there is effect in the reading comprehension ability to ward the achievement oflearning mathematics on the subject matter of the story test students class IV 02 Kertosari Elementary School in the academic year 2016/2017.
\end{abstract}

Keywords: Ability reading understanding, mathematic, story test

\begin{abstract}
ABSTRAK
Membaca, menulis dan berhitung merupakan kesatuan yang menjadi kebiasaan semua orang. Apalagi bagi peserta didik, tiada hari tanpa ketiga kegiatan tersebut. Ketika siswa mengalami hambatan dalam memahami isi soal cerita, maka siswapun sulit untuk menyelesaikan soal dengan baik. Dengan demikian, prestasi belajar siswa akan menurun karena berulang kali melakukan kesalahan dalam menyelesaikan soal. Tujuan dari penelitian adalah untuk membuktikan apakah terdapat pengaruh antara kemampuan membaca pemahaman terhadap prestasi belajar matematika pada pokok bahasan soal cerita kelas IV SDN 02 Kertosari Kabupaten Madiun tahun pelajaran 2016/2017. Penelitian ini merupakan penelitian kuantitatif. Populasi penelitian adalah siswa kelas IV SDN 02 Kertosari yang berjumlah 28 siswa dari dua sekolah di kelurahan Kertosari. Teknik sampling yang digunakan dengan teknik sampel jenuh, sehingga yang ada pada populasi digunakan sebagai sampel secara keseluruhan. Teknik pengumpulan data yang digunakan yaitu teknik tes pilihan ganda pada variabel $\mathrm{X}$ dan tes isian pada variabel $\mathrm{Y}$. Uji prasyarat yang dilakukan adalah uji normalitas, uji linearitas, dan uji homogenitas. Analisis data
\end{abstract}


penelitian menggunakan regresi linear sederhana dengan menghitung nilai a, nilai $b$, dan nilai $r$, nilai $t$, serta koefisien determinasi untuk mengetahui seberapa besar kontribusi antar variabel.Berdasarkan hasil penelitian, koefisien determinasi yang didapatkan adalah 0,5254 atau $52,54 \%$ dan sisanya dipengaruhi oleh variabel lain. Sehingga, dapat disimpulkan bahwa terdapat pengaruh kemampuan membaca pemahaman terhadap prestasi belajar matematika pada pokok bahasan soal cerita siswa kelas IV SDN 02 Kertosari tahun pelajaran 2016/2017.

Kata kunci: kemampuan membaca pemahaman, matematika, soal cerita.

\section{A. PENDAHULUAN}

Undang-Undang RI Nomor 20 Tahun 2003 mendefinisikan pendidikan sebagai usaha sadar dan terencana untuk mewujudkan suasana belajar dan proses pembelajaran sehingga peserta didik secara aktif mengembangkan potensi dirinya untuk memiliki kekuatan spiritual keagamaan, pengendalian diri, kepribadian, kecerdasan, akhlak mulia, serta keterampilan yang diperlukan, masyarakat, bangsa dan negara. ${ }^{1}$ Pada kenyataannya proses pembelajaran di dalam kelas lebih banyak diarahkan kepada siswa untuk menghafal informasi tanpa dituntut untuk memahami dan mengembangkan informasi yang diingat dalam kehidupan sehari -hari. ${ }^{2}$

Supatmono menyatakan

"semakin banyak orang ditanya apa itu matematika, semakin banyak pula pengertian tentang matematika." 3 Untuk selingan saja, anak-anakpun terkadang mengartikan matematika dengan cara yang unik. Ketika ditanya apa matematika? Jangan heran jika jawabannya:

\footnotetext{
${ }^{1}$ Pidarta, Landasan Kependidikan: Stimulus Ilmu Pendidikan Bercorak Indonesia, 11.

${ }^{2}$ Kusumawati, "PENGEMBANGAN MEDIA PEMBELAJARAN IPA DENGAN ANIMASI MACROMEDIA FLASH BERBASIS MODEL PENGAJARAN LANGSUNG (DIRECT INSTRUCTION) DI SEKOLAH DASAR," 264. ${ }^{3}$ Supatmono, Matematika Asyik.
}

\section{“Ma Te Ma Ti Ka = Makin Tekun Makin Tidak Karuan?????"}

Tujuan dari mata pelajaran matematika adalah agar peserta didik memiliki kemampuan untuk: (1)memahami konsep matematika dan menjelaskan keterkaitan antar konsep; (2)memecahkan masalah yang meliputi kemampuan memahami masalah, merancang model matematika, menyelesaikan model dan menafsirkan solusi yang diperoleh; dan (3)memiliki sikap menghargai kegunaan matematika dalam kehidupan, yaitu memiliki rasa ingin tahu, perhatian, dan minat mempelajari matematika.

Berbagai bentuk soal dapat digunakan untuk mengukur kemampuan siswa dalam pembelajaran matematika diantaranya berupa soal cerita dan noncerita. Memahami makna tujuan mata pelajaran matematika yang kedua, peneliti menyimpulkan bahwa tujuan tersebut berkaitan dengan penyelesaian soal cerita beserta langkah-langkahnya. Soal bentuk cerita merupakan bentuk soal yang menggambarkan permasalahan matematika yang berkaitan dengan kehidupan nyata sehari-hari atau bisa juga menggambarkan masalah lainnya.

Winarni dan Harmini 
menyatakan bahwa "soal cerita adalah soal matematika yang diungkapkan dengan kalimat dalam bentuk cerita yang dikaitkan dengan kehidupan seharihari."4 Pengertian soal cerita pada uraian di atas mengindikasikan bahwa siswa sudah seringkali menyelesaikan soal cerita. Langkah pertama untuk menyelesaikan soal cerita adalah dengan membaca dan memahami isi beserta maksud dari soal yang ada. Kemudian menuliskan hal-hal yang diketahui dan ditanyakan dari soal.

Selanjutnya mengubah isi soal dalam bentuk kalimat matematika dan menyelesaikannya. Oleh karena itu, kemampuan membaca pemahaman sangat dibutuhkan untuk dapat menyelesaikan soal cerita untuk menghindari terjadinya kesalahpahaman dalam memahami isi dan maksud dari soal. Soal cerita yang dimaksudkan dalam penelitian ini adalah soal matematika yan berbentuk cerita yang terkait dengan pokok bahasan FPB dan KPK yang diajarkan di kelas IV Sekolah Dasar.

Mulyati menyatakan bahwa kegiatan "membaca merupakan sesuatu yang penting sehingga perlu diajarkan sejak masih kanak-kanak. Seorang pembaca suatu waktu mungkin akan mengandalkan pengetahuannya mengenai topik yang telah diketahuinya guna mencari makna kata-kata yang

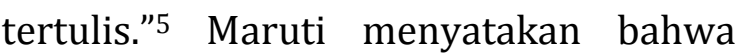
"membaca merupakan pembuka jendela informasi dunia". ${ }^{6}$ Pada abad global ini,

\footnotetext{
${ }^{4}$ Winarni dan Harmini, "Matematika untuk PGSD."

${ }^{5}$ Mulyati, Keterampilan Berbahasa Indonesia SD, 3.

${ }^{6}$ Maruti, Pembelajaran Bahasa Jawa di SD, 28.
}

setiap hari informasi mengalir sangat deras, baik melalui media elektronik maupun cetak, atau sarana lainnya. Salah satu penyampaian informasi yang bertahan lama dan berjangkauan luas adalah melalui bacaan. Oleh sebab itu, kemampuan membaca merupakan prasyarat mutlak bila seseorang ingin memperoleh kemajuan. Maruti menyatakan "membaca pemahaman merupakan suatu kegiatan membaca yang tujuan utamanya adalah memahami isi bacaan secara tepat dan cepat."7 Siswa yang memahami arti penting membaca pasti akan termotivasi untuk belajar, apalagi kegiatan membaca terlibat pada setiap aspek kehidupan. Kemampuan memahami isi bacaan tidak hanya diperlukan saat siswa mengikuti pelajaran Bahasa Indonesia. Hampir semua pelajaran membutuhkan kemampuan memahami isi bacaan, termasuk matematika yang sebagian besar berkaitan dengan berhitung.

Membaca, menulis dan berhitung merupakan kesatuan yang menjadi kebiasaan semua orang setiap harinya. Apalagi bagi peserta didik, rasanya tiada hari tanpa ketiga kegiatan tadi. Ketika siswa mengalami hambatan dalam memahami isi pada soal cerita matematika maka siswa pun akan sulit untuk menyelesaikan soal-soal tersebut dengan baik.

Dengan demikian prestasi belajar siswa juga akan menurun karena berulang kali melakukan kesalahan dalam menyelesaikan soal-soal matematika. Berdasarkan uraian diatas, penulis terdorong untuk mengadakan

\footnotetext{
${ }^{7}$ Maruti, 42.
} 
penelitian dengan judul "Pengaruh Kemampuan Membaca Pemahaman terhadap Prestasi Belajar Matematika pada Pokok Bahasan Soal Cerita Kelas IV SDN 02 Kertosari Tahun Pelajaran 2016/2017".

\section{B. METODE PENELITIAN}

Penelitian ini menggunakan pendekatan kuantitatif dengan jenis penelitian korelasional. Populasi dalam penelitian ini adalah SDN 01 Kertosari dan SDN 02 Kertosari pada bulan MaretAgustus 2017. Jumlah siswa dari SDN 01 Kertosari adalah 13 siswa, sedangkan dari SDN 2 Kertosari adalah 15 siswa. Sehingga total siswa secara keseluruhan adalah 29 siswa. Sampel dalam penelitian ini semua anggota dari populasi yang ada yaitu SDN 01 Kertosari dan SDN 2 Kertosari. Teknik sampling yang digunakan dalam penelitian adalah non probability sampling yaitu teknik sampling jenuh, yaitu bila semua anggota populasi digunakan sebagai sampel. Hal ini dilakukan bila jumlah populasi relatif kecil. Istilah lain sampel jenuh adalah sensus, dimana semua anggota populasi dijadikan sampel"8.

Teknik pengumpulan data pada penelitian ini menggunakan instrumen tes. Instrumen yang digunakan berupa soal pilihan ganda dan soal isian. Soal pilihan ganda untuk mengukur keterampilan membaca pemahaman siswa dan soal isian untuk mengukur prestasi belajar matematika pada pokok bahasan soal cerita siswa. Data yang diperoleh dalam penelitian ini dianalisis

\footnotetext{
${ }^{8}$ Sugiyono, Metode Penelitian Pendidikan (Pendekatan Kuantitatif, Kualitatif, dan R\&D), 124.
}

dengan menggunakan regresi linear sederhana. Teknik analisis data dibagi menjadi dua tahap, yaitu uji prasyarat analisis untuk memenuhi asumsi-asumsi dasar dan uji hipotesis menggunakan regresi sederhana. Uji prasyarat dan uji regresi sederhana dilakukan dengan bantuan program Microsort Excel 2007. Uji prasyarat yang digunakan meliputi uji normalitas, uji linearitas dan uji homogenitas.

Uji normalitas bertujuan untuk mengetahui sebaran data. Uji normalitas dilakukan menggunakan uji One Sample Kolmogorov-Smirnov. Jika nilai signifikansi > 0,05 maka data berdistribusi normal. Uji linieritas digunakan untuk mengetahui apakah dua variabel secara signifikan mempunyai hubungan yang linear atau tidak. Pengambilan keputusan linearitas dilihat pada kolom Deviation from Linearity, jika signifikansi $>0,05$ maka data dapat dikatakan berhubungan secara linier. Uji homogenitas digunakan untuk mengetahui sampel bersifat homogen atau tidak. Uji homogenitas dilakukan menggunakan uji Bartlet dimana jika ${ }^{2}$ hitung $\leq{ }^{2}$ tabel berarti sampel bersifat homogen.

Uji hipotesis dalam penelitian ini menggunakan regresi sederhana. Regresi sederhana bertujuan untuk meramalkan atau memprediksi variabel terikat (Y) apabila variabel bebas (X) diketahui. Jika nilai sig $>0,05$ maka Ho diterima. Jika nilai sig< 0,05 maka Ho ditolak. 


\section{HASIL PENELITIAN DAN PEMBAHASAN}

Sebelum diadakan pengujian analisis data hasil penelitian, perlu diadakan uji prasyarat analisis data yang terdiri dari uji normalitas, uji linearitas dan uji homogenitas. Setelah diadakan uji normalitas terhadap variabel-variabel penelitian yang terdiri dari kemampuan membaca pemahaman $(\mathrm{X})$ dan prestasi belajar matematika pada pokok bahasan soal cerita (Y) didapat hasil sebagai berikut.

1. Uji normalitas pemahaman menggunakan uji Kolmogorof Smirnov dihasilkan $D_{\text {hitung }}=$ 0,0982 dengan $\mathrm{n}=28$ dan taraf nyata $=0,05$ didapat $\mathrm{D}_{\text {tabel }}=$ 0,250 . Karena $D_{\text {hitung }}=0,0982<$ $D_{\text {tabel }}=0,250$ sehingga $\mathrm{H}_{0}$ diterima yang berarti bahwa sampel berdistribusi normal.

2. Uji normalitas prestasi belajar matematika pada pokok bahasan soal cerita menggunakan uji Kolmogorof Smirnov dihasilkan $D_{\text {hitung }}=$ 0,0982 dengan $\mathrm{n}=28$ dan taraf nyata $=0,05$ didapat $\mathrm{D}_{\text {tabel }}=$ 0,250. Dan $D_{\text {hitung }}<D_{\text {tabel }}$ sehingga $\mathrm{H}_{\mathrm{o}}$ diterima yang berarti bahwa sampel berdistribusi normal.

3. Uji linearitas model regresi linear sederhana $\mathrm{Y}=1,7405+$ $0,7988 \mathrm{X}$ dengan $=0,05$ dengan $\mathrm{dk}$ pembilang $5 \mathrm{dan} \mathrm{dk}$ penyebut 21 , didapat $\mathrm{F}_{\text {tabel }}=$ 2,68 Untuk uji kelinearan, didapat $F_{\text {hitung }}=0,301$. Karena $F_{\text {hitung }}=0,301<F_{\text {tabel }}$
$=2,68$ maka hipotesis bahwa model regresi linear diterima.

4. Demikian halnya untuk uji signifikansi, dari daftar distribusi $F$ didapat $F_{\text {tabel }}=4,23$ sedangkan $F_{\text {hitung }}=28,806$. Karena $\mathrm{F}_{\text {tabel }}=4,23<\mathrm{F}_{\text {hitung }}=$ 28,806 maka regresi bersifat signifikan.

5. Sampel dapat dikatakan homogen jika nilai ${ }^{2}$ hitung $<{ }^{2}$ tabel. Dari hasil penghitungan, dapat diketahui nilai dari ${ }^{2}$ hitung $=2,7773<{ }^{2}$ tabel $=12,59$.

Sehingga pernyataan $\mathrm{H}_{0}$ bahwa sampel bersifat homogen diterima dan $\mathrm{H}_{1}$ ditolak. dinyatakan bahwa sampel bersifat homogen atau berasal dari varians yang sama.

Hasil analisis data menunjukan bahwa kemampuan membaca pemahaman siswa kelas IV SDN 02 Kertosari dikategorikan pada tingkatan sedang dengan mean 69,82 dan median sebesar 71,5. Begitu juga prestasi belajar matematika pada pokok bahasan soal cerita berada pada kategori sedang dengan mean 73,2 dan median sebesar 69,75 . Analisis data dan uji hipotesis yang dilakukan menggunakan regresi sederhana dengan bantuan program Microsoft Excel, diperoleh hasil sebagai berikut.

1. Nilai korelasi (r) antara kemampuan untuk membaca pemahaman dengan prestasi belajar matematika pokok bahasan soal cerita yaitu sebesar 0,7248 .

2. Koefisien determinasi

$\left(\mathrm{r}^{2}\right)$ 
sebesar $\quad 0,5254 \quad$ yang

mengandung pengertian

bahwa pengaruh variabel

bebas (Kemampuan Membaca

Pemahaman) terhadap

variabel terikat (Prestasi

Belajar Matematika Pokok

Bahasan Soal Cerita) adalah

sebesar $52,54 \%$ sedangkan sisanya dipengaruhi oleh

variabel lain diantaranya mungkin karena faktor potensi akademik siswa, faktor panjang pendek soal, faktor sifat siswa yang beragam (rajin dan tidak), dan faktor-faktor lain yang belum diketahui oleh peneliti.

3. Berdasarkan penghitungan yang telah dilakukan, dihasilkan nilai $t_{\text {hitung }}=5,364>$ $t_{\text {tabel }}=1,706$ dengan demikian $\mathrm{H}_{\mathrm{a}}$ diterima, artinya hipotesis pengaruh kemampuan membaca pemahaman terhadap prestasi belajar matematika pada pokok bahasan soal cerita kelas IV SDN 02 Kertosari Kabupaten Madiun tahun pelajaran 2016/2017 telah terbukti.

4. Persamaan regresi $Y=1,7405+$ $0,7988 \mathrm{X}$. Hasil tersebut menunjukan bahwa kemampuan membaca pemahaman berpengaruh signifikan terhadap prestasi belajar matematika pokok bahasan soal cerita. Artinya semakin tinggi kemampuan membaca pemahaman siswa
SD kelas IV SDN 02 Kertosari, maka semakin tinggi pula prestasi belajar matematika pada pokok bahasan soal cerita.

Hasil diatas sesuai dengan uraian yang dikemukakan Dalman (2014:5) tentang pengertian membaca. Menurut Dalman membaca merupakan suatu kegiatan atau proses kognitif yang berupaya untuk menemukan berbagai informasi yang terdapat dalam tulisan. ${ }^{9}$ Hal ini berarti membaca merupakan proses berpikir untuk memahami isi teks yang dibaca. Memahami isi dari suatu teks bacaan merupakan salah satu langkah dalam penyelesaian soal cerita matematika, dengan begitu siswa akan dapat dengan mudah untuk menyelesaikan soal cerita yang diberikan.

Langkah-langkah dalam penyelesaian soal cerita menurut Winarni dan Harmini (2012:123) yaitu (1) temukan/cari apa yang ditanyakan oleh soal cerita itu; (2) cari informasi/keterangan yang esensial; (3) pilih operasi/pengerjaan yang sesuai; (4) tulis kalimat matematikanya; (5) selesaikan kalimat matematikanya; dan (6) nyatakan jawab dari soal cerita itu dalam bahasa Indonesia sehingga menjawab pertanyaan dari soal cerita tersebut. $^{10}$ Ada dua langkah yang berkaitan dengan kemampuan membaca pemahaman, yang pertama adalah temukan/cari apa yang ditanyakan oleh soal cerita itu dan yang kedua adalah cari

\footnotetext{
${ }^{9}$ Dalman, Keterampilan membaca, 5.

${ }^{10}$ Winarni dan Harmini, "Matematika untuk PGSD," 123.
} 
informasi/keterangan yang esensial. Untuk menemukan apa yang ditanyakan dan informasi yang esensial dalam penyelesaian soal cerita diperlukan kemampuan membaca pemahaman siswa yang tinggi. Dengan demikian dapat disimpulkan bahwa kemampuan membaca pemahaman berpengaruh cukup besar terhadap prestasi belajar matematika pada pokok bahasa soal cerita.

Hal ini diperkuat dengan artikel yang telah ditulis Yudiani, dkk dari hasil penelitiannya yang berjudul "Kontribusi Kemampuan Verbal Dan Kemampuan Membaca Pemahaman terhadap Prestasi Belajar Siswa dalam Menyelesaikan Soal Cerita Pada Pelajaran Matematika". Dari hasil penelitian tersebut dikemukakan bahwa terdapat kontribusi yang signifikan kemampuan membaca pemahaman terhadap prestasi belajar dalam menyelesaikan soal cerita pelajaran matematika pada siswa kelas 5 SD Gugus IV Kuta dengan persamaan garis regresi $\hat{Y}=4,502+0,428 X_{2}$ dan koefisien determinasi sebesar 61,3\%. Hal ini mengindikasikan bahwa kemampuan membaca pemahaman yang ditunjukkan siswa cukup optimal dalam mempengaruhi prestasi belajar dalam menyelesaikan soal cerita pelajaran matematika. Dengan kata lain dapat dikatakan bahwa semakin tinggi kemampuan membaca pemahaman yang ditunjukkan siswa, maka semakin tinggi pula prestasi belajar dalam menyelesaikan soal cerita pelajaran matematika.

Auzar juga menyatakan dalam artikelnya bahwa juga terdapat "Hubungan Kemampuan Membaca Pemahaman dengan Kemampuan Memahami Bahasa Soal Hitungan Cerita Matematika Murid-Murid Kelas 5 SD 006 Pekanbaru". Hasil dari penelitiannya dituliskan bahwa korelasi hubungan (r) sebesar 0,726. Berdasarkan kriteria yang berlaku, nilai (r) sebesar itu menunjukkan korelasi kemampuan membaca pemahaman dengan kemampuan memahami bahasa soal hitungan cerita digolongkan kuat $(0,60$ 0,799).

\section{SIMPULAN}

Berdasarkan hasil penelitian dan pembahasan yang telah diuraikan pada bab sebelumnya, dapat diambil kesimpulan bahwa terdapat pengaruh kemampuan membaca pemahaman terhadap prestasi belajar matematika pada pokok bahasan soal cerita kelas IV SDN 02 Kertosari Kabupaten Madiun tahun pelajaran 2016/2017. Kesimpulan ini diambil dengan membandingkan nilai $t_{\text {hitung }}$ yang lebih besar dari tabel $(5,364>$ 1,706). Melihat koefisien korelasi (r) yang nilainya 0,7248 menunjukkan bahwa pengaruh sangat kuat. Besar pengaruhnya ditentukan oleh koefisien determinasi $\left(\mathrm{r}^{2}\right)$ yang nilainya 0,5254 atau sebesar 52,54\%. Ini berarti bahwa prestasi belajar matematika pada pokok bahasan soal cerita dipengaruhi oleh kemampuan membaca pemahaman sebesar $52,54 \%$ dan sisanya dipengaruhi oleh keadaan lain.

Berdasarkan simpulan yang telah diuraikan, beberapa saran yang dapat disampaikan bagi kepala sekolah, bagi guru, bagi siswa, dan bagi orang tua 
adalah sebagai berikut.

1. Bagi guru hendaknya lebih menarik dalam penyampaian materi pelajaran sesuai dengan kompetensinya sehingga siswa merasa tertarik dan bersemangat dalam mengembangkan model pembelajaran yang digunakan dalam upaya meningkatkan kemampuan membaca pemahaman siswa.

2. Bagi siswa hendaknya perlu mengikuti kegiatan yang dapat meningkatkan kemampuan membaca pemahaman sehingga dapat meningkatkan kemampuan menyelesaikan soal cerita.

\section{DAFTAR PUSTAKA}

Dalman, H. Keterampilan membaca. Jakarta: Raja Grafindo Persada, 2013.

Kusumawati, Naniek. "PENGEMBANGAN MEDIA PEMBELAJARAN IPA DENGAN ANIMASI MACROMEDIA FLASH BERBASIS MODEL PENGAJARAN LANGSUNG (DIRECT INSTRUCTION) DI SEKOLAH DASAR." Premiere Educandum: Jurnal Pendidikan Dasar dan Pembelajaran 5, no. 02 (2016). Maruti, E.S. Pembelajaran Bahasa Jawa di SD. Madiun: CV. AE Media Grafika, 2015.

Mulyati, Yeti. Keterampilan Berbahasa Indonesia SD. Jakarta: Universitas Terbuka, 2015.

Pidarta, Made. Landasan Kependidikan:

Stimulus Ilmu Pendidikan

Bercorak Indonesia. Jakarta:

Rineka Cipta, 2007.

Sugiyono. Metode Penelitian Pendidikan

(Pendekatan Kuantitatif, Kualitatif, dan R\&D). Bandung: Alfabeta, 2013.

Supatmono, Catur. Matematika Asyik.
Jakarta: Grasindo, 2009.

Winarni, Endang Setyo, dan Sri Harmini.

"Matematika untuk PGSD."

Bandung: Remaja Rosdakarya, 2011. 